\title{
Leuser Mountain National Park Marketing Strategy In Optimalization Of Ecotourism Zone
}

\author{
Meizar Rusli ${ }^{1}$ and Teguh Pujiwioto ${ }^{2}$ \\ ${ }^{1}$ Universitas Pancasila \\ ${ }^{2}$ Universitas Azzahra
}

Email: ${ }^{1}$ meizar@univpancasila.ac.id and ${ }^{2}$ teguhdewi@gmail.com

\begin{abstract}
The competition of tourist attraction can not be run only on the basis of feeling alone but must be through good management. Appropriate marketing techniques can not work without good communication from the managers who will be delivered to the potential tourists and the tourists, because the good marketing quality and quantity is inseparable. Implementation of communication strategy in marketing can attract consumer interest that have a positive impact on the management such as increased visits and creating a good image for the management in the area of Ecotourism Leuser Mountain National Park. Through the review of secondary data sources based on related institutional reports, scientific articles, other information through digital data relating to research conducted with consideration of the results obtained through Importance-Performance Analysis. It is expected that these efforts can improve the quality of existing performance and minimize the problems or weaknesses that need to be improved so that the satisfaction of the Ecotourism tourists in the area of Leuser Mountain National Park can be fulfilled.
\end{abstract}

Keywords-Marketing Strategy, National Park, Leuser Mountain, IP Analysis

\section{INTRODUCTION}

Leuser Mountain National Park is one of the conservation areas that have potential in the tourism sector, especially ecotourism that can be managed as an effort to improve the welfare of both the province of Nangroe Aceh Darussalam and North Sumatra Province. By seeing and knowing the various potentials of Leuser Mountain National Park that can attract the attention of domestic tourists and foreign tourists to choose Leuser Mountain National Park as a tourist destination, so it is not excessive if tourism demands serious attention from the government as well as attention to other sectors as its supporters.

Based on the Decree of the Minister of Forestry no. 276 / KPTS-VI / 1997 dated May 23, 1997 on the Appointment of Leuser Mountain National Park area of MLNP increased to 1,094,692 Ha. Consisting of the Leuser Mountain Wildlife Reserve of 416,500 Ha, Kluet Wildlife Reserve of 20,000 Ha, Langkat Barat Wildlife Reserve of 51,000 Ha, Lawah Selatan Wildlife Sanctuary of 82,985 Ha, 79,500 Ha Sekundur Wildlife Reserve, Kappi Wildlife Reserve of 142,800 Ha, Lawe Gurah Tourist Park 9,200 hectares, Protected Forest and Limited Production Forest of 292,707 Ha. Area of MLNP Section of Management of National Park Region VI Besitang with an area of $\pm 126,000$ ha located in Langkat Regency is located in Besitang district, Sei Lepan, and Batang Serangan and partly in Aceh Tamiang Regency. For functuary working area is divided into 6 (six) resorts, namely Resort Trenggulun, Sei Betung, Sekoci, Sei Lepan, Cinta Raja, and Tangkahan (Ismail, 2010).

Leuser Mountain National Park Main Office is a government institution that has a very vital position for Leuser Mountain National Park, both as a conservation area and tourism management. Besides having the authority and responsibility to safeguard resources against environmental disturbance Leuser Mountain National Park Main Office seeks to stimulate and increase the flow of tourist visits. The arising problem is when the current market grows with the knowledge itself carries. Tourists no longer take part in traveling. The more intelligent in enjoying with the consequences of high demands that must be met by the Leuser Mountain National Park. According to Peter and Donnelly (2011: 2)"Marketing concept means that an organization should seek to make a profit by serving the needs of customer groups". Marketing concept emphasizes the fulfillment of the needs of consumers. Furthermore, both explain about marketing mix that is the set of controllable variables that must be managed to satisfy the target market and achieve organizational objectives. Based on the 
data obtained from the Office of Regional Section V Leuser Mountain National Park (MLNP) Bukit Lawang in 2013, domestic tourists visiting the Mount Lawang recorded 3,152 people and foreign countries 7,812 people. In 2014 although domestic tourist arrivals rose to 3,868 people, but foreign tourists dropped to 6,415 people. While in 2015 the level of local tourist arrivals also decreased to 3762 people and foreign tourists dropped dramatically only 3,485 people (Asl, 2016). Specifically, foreign tourist arrivals contribute 82 percent to EUROPE, 3 percent ASIA, 0.33 Africa, 7.7 America and 6.7 percent Australia (MLNP Main Office, 2014).

This research becomes important to be done in order to maximize the quality of tourist arrivals coming to Leuser Mountain National Park, not just to optimize the visit level. According to Mitchell et al. (2016) Users of the ecosystem approach must be sensitive to the practical needs of environmental management, otherwise the accepted conceptual approach will be unprofitable or acceptable. According to Yoon (2005), motivational motivation is more related to the internal emotional aspect, while the pulling motivation is connected to a situational external, or cognitive aspect. On the other side, the driving factors are the intrinsic desires of tourists, such as the desire to escape from routine, rest and relaxation, health and fitness, adventure, prestige, and social interaction. Meanwhile, the pull factor includes factors that arise as a result of the attraction of tourist destinations as perceived by the tourists. For example, natural tourist attraction, recreational facilities and accessibility, tourist perceptions and expectations such as something new, expected benefits, as well as the image of tourism destinations, including Leuser Mountain National Park as one tourist attraction. Lovelock and Wirtz (2011: 44) explains that the marketing mix of services is the core marketing tool of the service business, where the mix of service marketing is not only related to 4P product, price, place, promotion, but must be added another 3P process, physical, and people. Through the value-added approach and the value of the performance of what is offered, this research is very useful for the management in making decisions related to the fulfillment of ecotourism market mechanism. This research provides alternative strategies through the identification of secondary data and primary data though through the approach of important value and value of product performance ecotourism Leuser Mountain National Park.

\section{METHODS}

The research location is located in Gunung Leuser National Park located in Nangroe Aceh Darussalam Province and North Sumatera Province. This research uses qualitative and quantitative approach which focuses on holistic decomposition and conclusion with the existing data set in the field (based on secondary data through related institution reports, scientific articles, other information via internet site) in accordance with the focus of the research problem.

The data will be analyzed qualitatively and quantitatively. The following steps are analyzed: (1) data collection, (2) data interpretation, (3) data verification, and (4) drawing conclusions.This study uses Importance-Performance Analysis (Analysis of Performance Interest Level), this analysis technique was first proposed by John. A. Mortila and John C. James in Nasution, 2001. In this technique researchers rank various attributes or elements of the offer based on the importance of each attribute. In addition, respondents were also asked to rank how well the performance achieved.

\section{RESULTS AND DISCUSSION}

\section{A. Area Characteristics}

Zoning arrangement is a preconditioning activity, which is to arrange the spatial area by identifying and categorizing the area into spaces based on certain characteristics for the sake of management with attention to aspects of biodiversity, social, economic and cultural as well as the management aspect itself. As a management instrument, zoning is needed to facilitate the management, in the hope that every part of the national park area can be managed optimally in accordance with its potential, both the biological natural resources and its ecosystem and the external potentials of the area affecting the area, providing the greatest benefit to the welfare of society. So the dynamic condition of the area, of course, will result in no permanent zone in the region. This means that in the interest of managing zoning changes should be possible, even the changes can be done quickly. even revisions into activities that must be done regularly, at least 5 (five) years, so that the 
management of the area can be done well. From the result of data overlay in the form of data of spreading of flora and fauna, ecosystem type, Closing area, climate division, topography, geology and spreading of land type of Leuser Mountain National Park and community activity in the area, then in 8 zone types as follows :

TABLE I. ZONING LEUSER MOUNTAIN NATIONAL PARK

\begin{tabular}{lr}
\hline \multicolumn{1}{c}{ Zone } & \multicolumn{1}{c}{ Area $(\mathrm{Ha})$} \\
\hline Core & $857,175.64$ \\
Jungle & $66.921,08$ \\
Utilization & 12.431 .78 \\
Rehabilitation & $143.734,87$ \\
Traditional & 10.495 .03 \\
Religion & 73.27 \\
Special & $1.326,28$ \\
\hline Source: Main Office MLNP,2014
\end{tabular}

\section{B. Products}

As for some products that can be submitted based on data collected from Main Office MLNP (2014), among others:

\section{Amenity}

Facilities at Tangkahan include lodging facilities Bamboo River Lodge, has six double rooms equipped with bathroom. Rates range from Rp. 75,000 up to Rp. 100,000 per night. There is also another lodging with prices starting from Rp. 15,000 up to Rp. 150,000 per night. Other facilities available are visitor center, camping ground, and traditional food stalls owned by the local community. Many local youths work as guides at Tangkahan tourist sites. They are incorporated in a container called Tangkahan Tourism Institute (LPT).Facilities at Bukit Lawang include natural tourist lodges with rates varying between Rp. 100,000 up to Rp. 500,000 per night. Other tourist facilities available in the form of restaurants, camping ground, feeding site, and ferry boat to the Leuser area. In mount Lawang many experienced local tour guides are available.For visitors who need a guide during an adventure at Leuser can contact the Indonesian Guides Association (HPI) Bukit Lawang.

Tourist accommodation facilities are available at Kedah in the form of Tropical Rainforest Lodge's cottage and traditional food stalls. There is also a trail to the top of the mountain and waterfall "Uning". Accommodation and consumption facilities are also located in downtown Blangkejeren as the capital of Gayo Luwes Regency in the form of hotels and restaurants. The facilities available in Gurah tourist forest is a trail or trail that consists of several routes that can be passed by tourists without the need to be accompanied by a guide. The condition of the trail is generally in good condition, but it needs to be careful for the uphill track. Accommodation facilities available at tourist sites in the form of lodging facilities and restaurants. In addition there is also camping ground, animal observation tower, shelter, canteen, parking area and souvenir shop.

\section{Tourist Attractions}

Tangkahan is located in Namo Sialang Village, Batang Serangan Langkat North Sumatera with an area of about 17,000 hectares. The existence of Participatory Patrol using elephant, making Tangkahan as a tourist destination favored by local and foreign tourists. Between the 1980s and 1990s, people around Tangkahan were active in logging forest originating from Leuser Mountain National Park. But over time, people are aware of the damage and mistakes they have made. The agreement with the community in Tangkahan then decided to stop illegal logging from within the Leuser area and develop the Tangkahan ecotourism area. In 2001, the Tangkahan people gathered and agreed on village regulations that prohibited all illegal activities and established the Tangkahan Tourism Institute.

Bukit Lawang nature tourism became a mainstay in Leuser due to the rare wildlife attraction of the semi-wild Sumatran Orangutan and the panorama of tropical rain forest. Bukit Lawang or better known as the Center for Observation of Orangutan Sumatra is located in the Village Plantation Bukit Lawang, Bahorok Langkat North Sumatra. This area has an area of 200 hectares. At first Bukit Lawang is an orangutan rehabilitation center. But along with its development, this area developed into 
the Sumatran Orangutan Observation Center or Viewing Center. Currently Bukit Lawang become the mainstay attractions in North Sumatra are crowded visiting with the archipelago and abroad tourist. The main gate to enter the climbing lane of Mount Leuser is Kedah. A hamlet located in Penosan Sepakat Village, Blang Jerango Gayu Luwes Aceh. Kedah ecotourism area adjacent to Leuser Mountain National Park provides a special attraction for nature lovers to climb Leuser peak. Going to the top of Leuser and Loser takes about six to seven days. Leuser mountain panorama is very beautiful to look at from this location. On the topographical map there are two peaks adjacent to each other peak Leuser (3.319 M Above the sea level) and peak Loser (3.404 M Above the sea level).

The existence of Rafflesia as the largest flower in the world, Sumatran orangutans, kedih, natural hot springs, and waterfalls as well as tropical rain forests become a tourist attraction in Gurah. Gurah a hamlet located in Simpur Jaya Village, Ketambe Aceh, South East of Aceh. Hot springs become the main attraction for Gurah. The source of hot water comes from the crevices of rocks on the banks of the Gurahriver. The water is warm enough and not too hot so it is possible to bathe in it. The location is also interesting as a camping and trekking location to roam the forest. In the vicinity of this hot water object there is the famous Rafflesia flower in The World. Besides the natural attractions, in Gurah is also famous for an attractive local culture. Traditional art that has been worldwide is Saman dance which is often called Thousand Hand Dance. In addition to Saman, there is also a Masekat dance that combines hand and body movements with chanting poems containing religious guidance and community life. The poems are sung by dancers while performing dance moves. Masekat is usually played by men.

Flora

Vegetation in the LMNP region includes the Sumatra flora and is closely related to the flora of Peninsular Malaysia, Borneo Island, Java Island and even the Philippines. The natural vegetation formation at LMNP is based on 5 criteria, namely bioclimate (altitude climatic zone with various floristic formations). Four other criteria are the relationship between floristic composition with biogeography, hydrology, type of bedrock and soil. Van Steenis conducted the research in 1937 (de Wilde W.J.J.O and B.E.E. Duyfjes, 1996), dividing the plant areas in LMNP in several zones:

Tropical Zone (including Colline zone, located 500 - $1000 \mathrm{~m}$ Above the sea level). Tropical Zone is a heavily forested area covered by various types of wooden stands with large diameter and height up to 40 meters. The tree or wooden stand is used as a tree of liana plants and interesting epiphytes, such as orchids, and others. The transition zone from the Tropica Zone to the Colline Zone and the SubMontane Zone is characterized by an increasing number of beautiful flowering plants and different species due to altitude differences. The higher a place the more trees are reduced, the liana type begins to disappear and more and more rattan species are found.Montane Zone (including sub montane zone, located 1000 - $1500 \mathrm{~m}$ Above The Sea Level). The montane zone is a montane forest. Wood stands are no longer too high only ranging from 10 to 20 meters. There is no more liana plant species. Moss covered many wooden or tree stands. The humidity of the air is very high and almost every time it is covered in fog.Sub Alphine Zone (2900 - 4200 m Above The Sea Level), is an Ercacoid forest zone and no longer trees. This forest is a thick layer of mixture of dwarf trees and shrubs with some towering umbrella trees (families Ericacae) as well as several types of tundra, orchids and moss.

\section{Fauna}

In terms of geographical wildlife, the island of Sumatra is classified into Sub Regional Malaysia. While on the island of Sumatra can be set two fauna boundary lines, namely Bukit Barisan Mountains (the West and East) and Padang Sidempuan (the North and South). Other fauna boundaries are found in the translucent Wampu River from Tanah Karo Mountains cutting off South Langkat area. The Kedih species located east of the Wampu River are different from those in the west. The richness of fauna in LMNP is actually found in the area located at an altitude of $0-1000 \mathrm{~m}$ Above The Sea Level. In higher areas, the composition of the fauna is changing and its existence is limited.

LMNP is a habitat of mammals, birds, reptiles, amphibians, fish, and invertebrates. This area is also some birds habitat with a list of 380 species and 350 of which are sedentary living species. It is predicted that 36 out of 50 species of endemic birds in Sundaland can be found in the LMNP area. Of the 129 species of large and small mammals throughout Sumatra, 65\% are located in this national park area. LMNP and surrounding areas called the Leuser Ecosystem (LE) are the habitat of Sumatran elephants (Elephas maximus sumatranus), Sumatran tiger (Panthera tigris sumatrae), Sumatran rhino 
(Dicerorhinus sumatrensis), Sumatran Orangutan (Pongo abelii), Siamang (Hylobates syndactylus syndactylus), Owa (Hylobates lar), Kedih (Presbytis thomasi).

Price

Entrance tickets for visitors are charged Rp 5.000 on weekdays and Rp 7,500 on weekends, while foreign tourists are charged Rp 150,000 and Rp 225,000 on weekends. Until now, visitors who come to MLNP generally are foreign tourists who want to see orangutans or elephants.Currently non-tax state revenues that MLNP collected from the daily levy of visitors from the tourism sector is about Rp. 600 million per year, with a turnover of Rp 50 billion from all ecotourism activities, including admission, accommodation, food / beverage, scouting and other activities requiring assistance such as packages with elephants, trekking and tubing.

Place

Reaching the Tangkahan location can be reached from the city of Medan about 3 hours driving through the city of Binjai and Tanjung Pura. Condition of the road is good and has been paved. Another route by way of cutting City Stabat-Simpang Sidodadi with travel time faster one hour. However, alternative roads are not good enough and not all of them are terrestrial, especially in plantation areas.Achieving Bukit Lawang can be reached by road trip from Medan City of North Sumatra. Continuing to pass through Binjai City by public transportation through Pinang Baris bus terminal Medan. Can also be taken using private vehicles with travel time about 2.5 hours from the city of Medan.

Kedah hamlet can be reached from Blangkejeren by taking regular public transportation Kutapanjang / Blang Jerango which is about $9 \mathrm{~km}$. Followed by pedicab ride to the hamlet Kedah as far as $5 \mathrm{~km}$. Then can also by chartering public transport from Blangkejeren to Kedah. In the South Kedah hamlet there is also the object of waterfall "Uning". The location can be reached about an hour by foot. Distance about $2.5 \mathrm{~km}$ to the South of Kedah.Accessibility of Gurah tourism forest is very easy to reach. From the city of Medan to Kutacane can be reached within about 6 hours by taking public transport type minibus L300 or Kijang are widely available on Jl. Jamin Ginting Medan. Furthermore from Kutacane to Gurah tourist forest area quite a lot of public transport that routinely serving this route.

\section{Promotion}

From the results of secondary data observations, as for some findings that can be conveyed related to the promotion of Gunung Leuser Mountain National Park, namely:

1. Advertising

Regular activities of Leuser Mountain National Park conducting advertising activities through online media becomes an important choice such as website http://www.gunungleuser.or.id/jasalingkungan/wisata-alam/.

2. Personal Sales

Organizing a Tourism Exhibition, while the market segments and targets of Leuser Mountain National Park are special interest tourists, currently dominating is the European tourist .

3. Sales Promotion

Leuser Mountain National Park provides sales promotion program or often abbreviated as promo is the main element in marketing campaign. Leuser Mountain National Park collaborates with the Association of the Indonesian Tours and Travel Agencies (ASITA), as well as local government and national level .

4. Publicity

Publicity what has done is not vary much different with the media advertising such as print and electronic media, including newspapers, magazines and websites. One of the activities what has done is the publication of private television program activities and the visit of Leonardo de Caprio. Of the four elements of mix promotion that have been presented, the authors draw the conclusion that advertising, personal selling, sales promotions, and publicity help marketing as a form of promotional activities that facilitate directly or indirectly introducing a product to the community and stimulating customers to visit Leuser Mountain National Park .

5. People

The organizational structure of LMNP management currently refers to Forestry Minister's Regulation no. P.03 / Menhut-II / 2007 on Organization and Work Procedures in Main Office management of the Leuser Mountain National Park . MLNP's Main Office management is one of 
the Technical Implementation Unit of Directorate General of PHKA led by Head of The Main Office Management (Echelon IIb) assisted by 5 (Echelon IIIb and 11 (eleven) Echelon IVb. At the technical level, MLNP partners with ASITA, HPI, Conservation Cadres, Nature Lovers Group, NGO and Conservation Profession Groups.

6. Procces

Based on collected secondary data can be submitted process every visitor who carry out activities in Leuser Mountain National Park area must:

a. Visitor service starts at $08.00-15.00 \mathrm{WIB}$.

b. Administrative payments in accordance with applicable provisions.

c. Reporting to the local MLNP officers before and after the activities.

d. Submiting a copy of identity (identity card / driving license / student card / passport is still valid).

e. Things that need to be considered:

1) Complying with the instructions on the guidance / information boards as well as on information submitted by MLNP officers.

2) Keeping speech and behavior out of arrogant words and inappropriate deeds.

3) Staying alert to snake hazards, slippery roads, landslide-prone areas, and poisonous characteristics/species of flora and fauna.

4) Carrying equipment to the appropriate field include: Bringing enough logistics, equipment and equipment to suit the purpose of the visit; Using clothes of a rather thick and longsleeved cloth, comfortable shoes, not slippery; Bringing P3K drugs such as headache, stomach pain, wound medicines, malaria drugs, anti-toxins / poison, creams to prevent skin burns and personal medicines; Bringing a guide book or binoculars, a magnifying glass when going to observe animals / plants; Bringing a plastic bag for use during the trip as a place to garbage / dirt.

7. Physical Evidence

Physical Evidence of ecotourism area of Leuser Mountain National Park (Infrastructure facilititations such as road condition to location, information center, parking area, direction) are generally available in good condition. Physical Evidence (physical evidence) is important in shaping the image or perception of ecotourism of Leuser Mountain National Park.

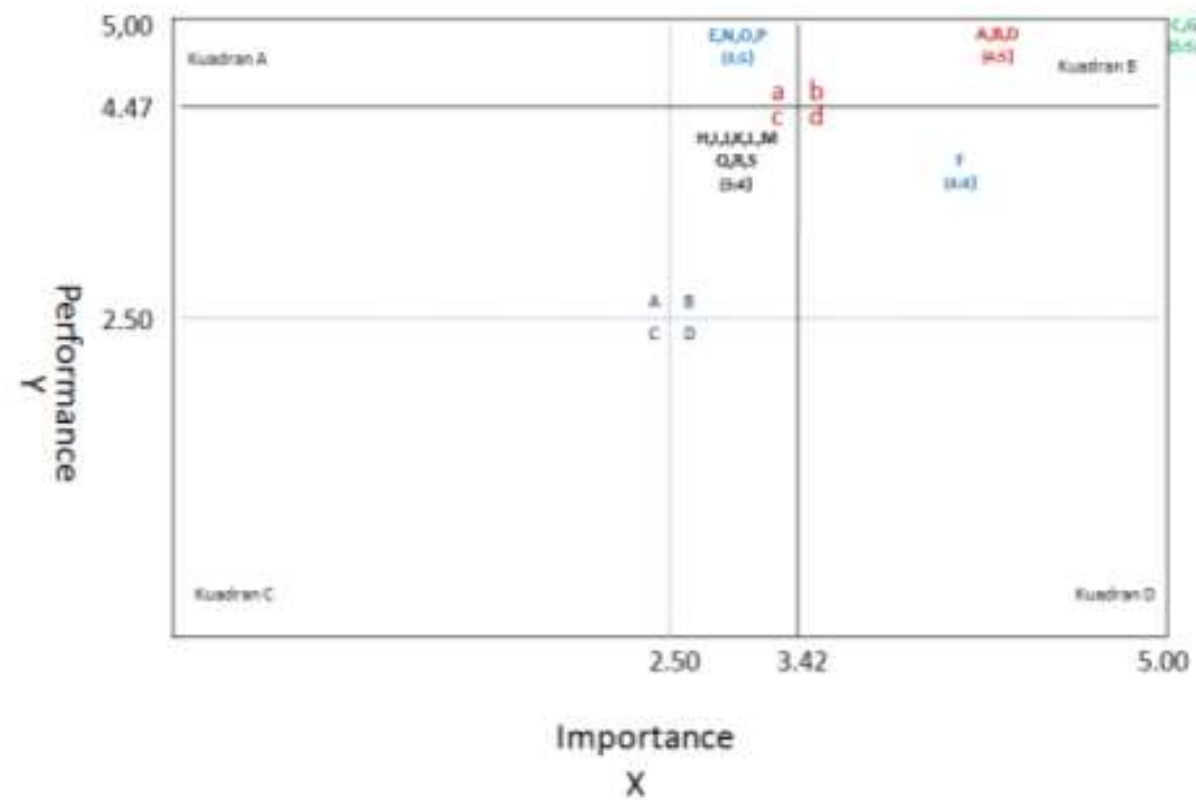

FIG I. DISTRIBUTION OF CARTESIAN DIAGRAM

Source: Research Results, 2017

Based on the results of the importance and performance analysis in the Table with the assumption that the middle value $\mathrm{X}=2.50$ and $\mathrm{Y}=2.50$ found that with the overall value $\mathrm{X}=3.42$ and $\mathrm{Y} 4.47$. 
The attributes contained in quadrant A have a high degree of importance, but their performance is still low resulting in the attributes contained in this quadrant must be prioritized for improvement. The attributes contained in this quadrant include Empathy-Product (Understanding MLNP Tourist Needs), Assurance (Capability, Professionalism and Professional Skills), Responsiveness (Responsiveness and Alertness) and Empathy-People (Understanding Customers).

Attributes contained in quadrant B have a high degree of importance and performance is also considered good. The attributes contained in this quadrant represent the strength or superiority of management. MLNP's tour operators need to maintain the quality and maintain the performance of these attributes. The attributes contained in this quadrant include Availability of Attractive Tour Packages, Availability of Accommodation, Reliable (Compliance with Media MLNP Promotion).

The attributes contained in quadrant $\mathrm{C}$ have low importance and management performance is considered poor. The management of MLNP needs to improve the performance of these attributes in order to prevent this attribute from shifting to quadrant A. Attributes contained in this quadrant include the availability of Board Direction, Ease of Access to MLNP Area (provisions of ecotourism), Advertising, Sales Promotion, Publicity, Personal Selling, certainty of obtaining the information (getting service until evaluation of the implementation by tourists), Availability of Information Center, Easy Access from Main Gate (Terminal / Airport / City) to the front door of MLNP.

The attributes contained in quadrant $\mathrm{D}$ have low importance according to the respondent but have good performance so that it is considered excessive. The attributes contained in this quadrant are Price Clues. Alternative strategies that can be done based on the results of Importance-Performance Analysis (IPA), namely:

1. Conducting training and Comparison study at national parks that are considered better especially in optimizing the quality of human resources in handling the needs of European tourists related to language, knowledge of MLNP, way of communication and handling problems if needed.

2. Maintaining existing quality on an ongoing basis through market analysis and development of environmental services in the national park area, especially at the technological level.

3. Establishment of a promotional team focused on European tourists. In addition, improving the physical needs related to access and supporting facilities in achieving MLNP in accordance with the rules of ecotourism.

4. Strenghtening cooperation with local governments, surrounding communities, Travel Bureau, and nature lovers related to the arrangement of supply in the fulfillment of demand in order to create a business situation and the existence of a sustainable environment.

\section{CONCLUSION}

Leuser Mountain National Park has its own uniqueness as an ecotourism attraction in Sumatera. Based on analysis of marketing mix indicators through the calculation of Importance-Performance Analysis, quality and importance in the field of human resources (people) become a priority for quality improvement. Strategies that can be implemented based on the priority scale are: Improving the quality of human resources both at the level of management as well as technical guidance tourists, the formation of a special promotion teams of the European market as the main market targets and the last is the active communication with relevant agencies both private and government.

\section{REFERENCES}

Asl.(2016). Visit to Bukit Lawang decline. http://harian.analisadaily.com/sumut/news/kunjunganwisatawan-ke-bukit-lawang menurun/230737/2016/04/18 Retrieved 09 May, 2017

Ismail.(2010). Final Report of Pride Campaign Program-Mountain Leuser National Park Besitang Area, North Sumatera. Yayasan Orangutan Sumatera Lestari - Orangutan Information Centre (YOSL-OIC). http://www.rareplanet.org/sites/rareplanet.org/files/Final_Report-Besitanggabung-sw_format310810_0.pdf Retrieved 09 May, 2017

Lovelock, Christopher, and Jochen Wirtz.(2011).Service Marketing, People, Technology, Strategy.Prentice Hall Upper Sadle River. 
Main Office MLNP.(2014). Ecotourism Mountain Leuser National Park. http: //gunungleuser.or.id Retrieved 17 April, 2017

Mitchell B, Setiawan and Rahmi H Dwita.(2016).Resource and Enviromental Management.Gajah Mada University Press.

Nasution, M.N.(2001).Total Quality Management.Ghalia Indonesia.

Peter, J.Paul dan Donelly, James H.(2011).Marketing Managenement:Knowledge and Skills. Tenth Edition.Mc Graw Hill.

Yoon, Y., Uysal, M .(2005). An Examination Of The Effects Of Motivation And Satisfaction On Destination Loyalty: A Structural Model, Tourism Management. 26 (1), 45-56 (2005).

Appendix 1 Calculation of Importance and Performance Value based on supply marketing mix of Leuser Mountain National Park. 